\title{
Appellate Review of Criminal Change of Venue Rulings: The Demise of California's Reasonable Likelihood Standard
}

The criminal defendant's right to a fair and impartial trial in the California courts is guaranteed by the United States ${ }^{1}$ and California ${ }^{2}$ constitutions. Fundamental to this right is a trial free from prejudicial pretrial publicity. ${ }^{3}$ One way courts can avoid the prejudice of pretrial publicity is to grant a defendant's motion for change of venue. ${ }^{4}$ In Maine v. Superior Court, ${ }^{5}$ the California Supreme Court adopted a liberal standard for reviewing change of venue notions and held that a change of venue inust be granted whenever pretrial publicity creates a "reasonable likelihood" that the defendant caunot have a fair trial without such relief. ${ }^{6}$ Maine directed the appellate courts to apply this standard when reviewing a trial court's ruling on a change of venue motion. ${ }^{\text {? }}$

1. U.S. CoNST. amends. VI, XIV. The sixth amendment right to jury trial has been made applicable to the states via the fourteenth amendment. Duncan v. Louisiana, 391 U.S. 145 (1968). The right to jury trial guarantees the defendant a fair trial by a panel of impartial, "indifferent" jurors. In re Murchison, 349 U.S. 133 (1965).

2. The criminal defendant's right to jury trial is guaranteed by CAL. ConST. art I, $\S 16$ ("Trial by jury is an inviolate right and shall be secured to all . . . ."). Even prior to Duncan $v$. Louisiana, the California courts recognized that the defendant was entitled to a fair trial in the state courts. See People v. Mahoney, 201 Cal. 618, 627, 258 P. 607, 610 (1927).

3. Irvin v. Dowd, 366 U.S. 717, 726 (1960) (where "adverse publicity caused a sustained excitement and fostered a strong prejudice" against the defendant, his right to a fair and impartial trial was violated). Where the media disseminate prejudicial or inadmissible information prior to trial, the defendant's due process rights are violated. Rideau v. Louisiana, 373 U.S. 723, 726 (1963) (media coverage of defendant's uncounseled confession held to be a violation of his due process rights).

Another issue raised by prejudicial pretrial publicity, the potential conflict between freedom of the press under the first amendment and the due process right to a fair trial, is outside the scope of this Comment. For a discussion of this issue, see ABA Comm. ON Falr Trial \& Free Press, Standards Relating to Fair Trial and Free Press (1966) [heremafter cited as Reardon REPORT]; Sturm, Judicial Control of Pretrial and Trial Publicity: A Reexamination of the Applicable Constitutional Standards, 6 GoldEN GATE U.L. REv. 101 (1975).

4. Maine v. Superior Court, 68 Cal. 2d 375, 382-83, 438 P.2d 372, 376-77, 66 Cal. Rptr. 724, 728-29 (1968).

5. 68 Cal. 2d 375, 438 P.2d 372, 66 Cal. Rptr. 724 (1968).

6. Id at 383,438 P.2d at 377, 66 Cal. Rptr. at 729. See CAL. Penal Code $\$ 1033$ (a) (West Supp. 1982).

7. $68 \mathrm{Cal} .2 \mathrm{~d}$ at $384 \mathrm{n} .9,438$ P.2d at $378 \mathrm{n} .9,66$ Cal. Rptr. at 730 n.9. 
This Comment demonstrates that the California courts have departed from the Maine reasonable likelihood standard and argues that that standard should be restored. The Comment is divided into three parts. Part I discusses the development and characteristics of the state and federal standards for change of venue. Part II shows that Califorma courts have retreated froin the reasonable likelihood standard by applying a more stringent standard for postconviction review, and by adopting, in effect, the federal standard for change of venue appellate review. Part III presents two alternative reform proposals for restoration of the reasonable likelihood standard.

\section{I \\ LEGAL BACKGROUND}

This Part reviews change of venue precedent. Section A discusses the alternative federal tests for determining whether a state court's demal of a change of venue motion is consistent with due process. Section B traces the development of the California reasonable likelihood test for evaluating a change of venue ruling.

\section{A. Alternative Federal Tests for Change of Venue}

Under the United States Constitution, a defendant may challenge a state court's denial of his change of venue motion by showing that prejudicial publicity in the original venue has produced either "inherent prejudice" or "actual prejudice." The federal Constitution requires a state court to grant a change of venue whenever either of these tests is satisfied. Failure to grant a change of venue may result in reversal of the conviction or a successful habeas corpus petition. ${ }^{8}$

While both federal tests are primarily concerned with the effect of prejudicial publicity, the tests differ with respect to the evidence used to determine whether an impartial jury can be found. The "actual prejudice" test focuses on the results of voir dire. ${ }^{9}$ If the defendant can

8. See People v. Tidwell, 3 Cal. 3d 62, 76, 473 P.2d 748, 758, 89 Cal. Rptr. 44, 54 (1970). A criminal defendant convicted in state court may seek fcderal court review of the denial of his change of venue motion. Pursuant to 28 U.S.C. $\$ 2254$ (1976), he may do so in a petition for a writ of habeas corpus, ou the basis that his constitutional due process right to a trial by impartial jurors was violated.

9. The courts' apphication of the actual prejudice test is not always confined to the results of voir dire. In Murphy v. Florida, 421 U.S. 794 (1975), the Supreme Court suggested it was employing a "totality of circumstances" test that-included consideration of "general community atmosphere." Id. at 802. See Goldsmith, Due Process Denial Not Presumed When Knowledge of Past Misdeeds Is Possessed By The Jury: "Totality of Circumstances" Test Will Be Used to Determine Fairness of Trial-Murplyy v. Florida, 42 I U.S. 794 (1975), 13 AM. Crum. L. Rev. 285, 289 (1975); Bronstein v. Wainwright, 646 F.2d 1048 (5th Cir. 1981) (court considered voir dire in context of inherent prejudice test, rather than actual prejudice test). The actual prejudice test, as analyzed in this Comment, is defined as a test based on the results of voir dire. According to the United States 
show, through voir dire, that any of the jurors held a sufficiently strong opinion about the defendant's guilt or innocence prior to trial, a change of venue should be granted. ${ }^{10}$ Alternatively, if pretrial or trial publicity is sufficiently prejudicial and widespread, a change of venue will be granted on the grounds that "inherent prejudice" exists, irrespective of the results of voir dire.

\section{Development of the Actual Prejudice Test \\ a. Origins of the Actual Prejudice Test}

The requirement that jurors be impartial is of venerable origin. ${ }^{11}$ The actual prejudice test is derived from cases establishing the standard for challenging jurors for cause on the grounds of partiality. As stated in Reynolds $v$. United States, ${ }^{12}$ a juror is excused for partiality when "the nature and strength of the opinion formed are such as in law necessarily . . . raise the presumption of partiality." 13 A positive and decided opinion is enough, while a light impression is imsufficient. This standard has been used to determine whether pretrial publicity has prejudiced jurors so much that a change of venue or contimuance is necessary to ensure a fair trial. ${ }^{14}$

\section{b. The Issue of Actual Prejudice in Change of Venue Rulings}

In Irvin v. Dowd, ${ }^{15}$ the United States Supreme Court held that as long as a juror could render a verdict based on the evidence presented, it was of no consequence that he had a preconceived opinion concerning the defendant's guilt. Irvin is the seminal case applying the actual prejudice standard to review of change of venue motions. Its test re-

Supreme Court, such a test cannot be satisfied unless the the defendant establishes "the actual existence of such an opinion in the mind of the juror as will raise the presumption of partiality ...." Murphy v. Florida, 421 U.S. at 800; Irvin v. Dowd, 366 U.S. at 723.

10. See Irvin v. Dowd, 366 U.S. 717 (1961).

11. The requirement that jurors be impartial is of ancient vintage. Lord Coke observed that jurors must be "indifferent" before hearing evidence of defendant's guilt at trial. 1 LORD COKE, COMMENTARY ON LITTLETON § 155b (Hargrave \& Butler ed. 1823).

Before a juror would be cousidered partial, however, his opinion had to be founded on "soine evidence." A juror with a "mere inupression" not founded on some evidence was inpartial. On the other hand, a juror with "strong and deep impressions which close the mind against the testiinony that may be offered in opposition to thein" was considered partial. Reynolds v. Umited States, 98 U.S. 145, 155 (1878).

12. 98 U.S. 145 (1878).

13. Id. at 156.

14. In Stroble v. California, 343 U.S. 181 (1952), the United States Supreme Court first addressed the issue of whether inflammatory pretrial publicity inade a fair trial impossible. The Court concluded that the defendant had made no affirmative showing that cominumity prejudice or jury prejudice existed, or that the jury's deliberations were affected. Id. at 195.

15. 366 U.S. 717 (1961). 
quires evidence of actual prejudice caused by pretrial publicity. ${ }^{16}$

Although the Irvin Court declined to establish a constitutional standard for judging jurors' impartiality in the cliange of venue context, and directed instead that the issue be decided on a case-by-case basis, ${ }^{17}$ the Court did provide solne guidance. The Court apparently equated an impartial juror with Lord Coke's "indifferent" juror, ${ }^{18}$ but inade it clear that the requirement of indifferent jurors did not mean that potential jurors had to be coinpletely ignorant about the case. ${ }^{19}$ It stated that the "inere existence of any preconceived notions as to the guilt or innocence of the accused, without more, [would not] rebut the presuinption of prospective juror's impartiality . . . ."20 If a juror can lay aside any preconceived opimion about the defendant's guilt and render a verdict based on evidence presented at trial, the presumption of impartiality should be uplield.21 To do otherwise, the Court asserted, would be to establish an impossible standard. Citmg Reynolds, the Court stated that when one challenges the demal of a change of venue inotion, one bears the burden of demonstrating "the actual existence of such an opimion in the mind of the juror as will raise the presumption of partiality."22

\section{Development of the Inherent Prejudice Test \\ a. Origins of the Standard}

The focus and burden of proof underlying the inherent prejudice test flow froin its rationale. The rationale underlying the inherent prejudice test is that the circumstances surrounding the trial may be so inflaminatory that the defendant caimot obtain a fair trial, even if twelve jurors declare they can be impartial. Thus, the inherent prejudice test focuses on the circumstances and publicity of a given case. If the requirements are inet, the trial court must conclude, without considering the results of voir dire, that a presumption of prejudice lhas arisen. ${ }^{23}$ Consequently, the burden of proof required under the $\mathrm{m}$ herent prejudice test is more onerous than that of the actual prejudice test; the defendant must slow circumstances so egregious that the court

16. The Irvin Court based its holding on fourteenth amendment due process grounds alone; the sixth amendment right to jury trial had not yet been incorporated via the fourteenth amendment's due process clause. $I d$. at 721-22.

17. Id. at 724-25.

18. "He that is of a jury, must be . . one that hath such freedome of mind as he stands indifferent as he stands unsworne." 1 LORD COKE, supra note 11.

19. 366 U.S. at $722-23$.

20. Id. at 723 .

21. Id.

22. Id.

23. See Murphy v. Florida, 421 U.S. 794, 799 (1975); Rideau v. Louisiana, 373 U.S. 723, 726 (1963). 
need not even pause to consider voir dire. ${ }^{24}$

Sheppard v. Maxwell ${ }^{25}$ was the first case to suggest that a reasonable likelihood standard for evaluating pretrial publicity might be required under the federal Constitution. ${ }^{26}$ In Sheppard, there was virulent and incriminating publicity about the defendant before and during the trial. The trial itself was conducted in a carnival atmosphere pervaded by newspaper and television reporters. ${ }^{27}$ Language in the Sheppard opinion suggested that a liberal standard should be applied in evaluating the potential prejudice resultimg from media coverage. Specifically, the Sheppard Court stated that "where there is a reasonable likelihood that prejudicial publicity prior to trial will prevent a fair trial, the judge should continue the case until the threat abates, or transfer it to another county not so permeated with publicity."28 Thus, Sheppard declared that a reasonable likelihood standard was needed to protect the defendant's right to a fair trial. Yet by not holding that reasonable likelihood was constitutionally mandated, the Court left some uncertainty as to the standard state courts must use in considering motions for change of venue. ${ }^{29}$

\section{b. The Current Inherent Prejudice Standard}

The confusion caused by Sheppard was, at least at the federal level, temporary. In Murphy v. Florida ${ }^{30}$ the Supreme Court declined to follow, and did not even discuss, the reasonable likelihood standard suggested in Sheppard. Instead, Murphy clarified the meaning of Sheppard by characterizing it as a case im which the level of publicity both before and during trial was so prejudicial as to create a conclusive presumption of prejudice, ${ }^{31}$ which the Court called "inherent prejudice." Thus, Murphy made it clear that the reasonable likelihood standard hinted at in Sheppard is not required by the federal Constitution. In fact, although it did not purport to apply the inherent prejudice test, but rather a reasonable likelihood test, Sheppard is one of three cases that have subsequently been characterized as examples of inherent prejudice. $^{32}$

Murphy has come to be understood as clarifying that there are two

24. See infra text accompanying notes $70-71$.

25. 384 U.S. 333 (1966).

26. Id. at 362-63.

27. Id. at 358.

28. Id. at 363.

29. See infra text accompanying notes $45-48$.

30. 421 U.S. 794 (1975).

31. Id. at 798-99.

32. People v. Hillery, 10 Cal. 3d 897, 900, 519 P.2d 572, 574, 112 Cal. Rptr. 524, 526 (1974); People v. Manson, 61 Cal. App. 3d 102, 183, 132 Cal. Rptr. 265, 313-14 (2d Dist. 1976), cert. denied, 430 U.S. 986 (1977). 
alternative grounds upon which a federal court may overturn a state court conviction when a change of venue has been denied. One alternative is a showing of actual prejudice, as illustrated by Irvin. ${ }^{33}$ Failing that, a conviction inay be reversed if the kind of inherent prejudice exemplified in Sheppard can be demonstrated. ${ }^{34}$ Thus, Murphy dispels the confusion caused by Sheppard by making it clear that the two alternative federal tests are the actual and inherent prejudice standardsthe Supreine Court appears to have abandoned the reasonable likehhood standard in the context of constitutional review of state court change of venue rulings.

\section{B. The California Reasonable Likelihood Standard}

\section{The Pre-Maine Change of Venue Standard}

Prior to Maine v. Superior Court, ${ }^{35}$ the California Penal Code gave trial courts the discretion to grant a change of venue "on the ground that a fair and impartial trial cannot be had in the county." 36 Under the controlling case law, the California appellate courts employed an "abuse of discretion" test when reviewing appeals of change of venue rulings made pursuant to this standard. ${ }^{37}$ To prevail on appeal, the defendant was required to show "prejudicial error in the denial of a

33. 366 U.S. at 723.

34. The Murphy Court concluded that the petitioner had "failed to show that the setting of the trial was inherently prejudicial or that the jury-selection process . . . permits an inference of actual prejudice." 421 U.S. at 803 . In Bronstein v. Wainwright, 646 F.2d 1048 (5th Cir. 1981), for example, the Fifth Circuit affirmed the denial of a habeas corpus petition and rejected the argument that the petitioner was denied a fair trial because the trial court had denied his motion for a change of venue. Relying on language in Irvin and Murphy, the court stated:

[I]n order to establish a deprivation of due process, [the defendant] must show that potential jurors were actually prejudiced by the pretrial publicity .... However, when the defendant proffers evidence of pervasive community prejudice in the form of highly inflammatory publicity or intensive media coverage, prejudice is presumed and there is no further duty to establish actual bias.

Id. at 1051 . Other federal courts liave articulated the standard in similar fashion. See Brinlee v. Crisp, 608 F.2d 839, 846 (10th Cir. 1979) ("We feel that the record does not demonstrate that the setting of the trial was inherently prejudicial or that the jury selection process permits an inference of actual prejudice."), cert. denied, 444 U.S. 1047 (1980); Haney v. Rose, 642 F.2d 1055, 1060 (6th Cir.) ("[W]e cannot conclude that Haney did not receive a fair trial. He has failed to show that the setting of the trial was inherently prejudicial or that the [jurors' knowledge] permits an inference of actual prejudice."), cert. denied, 452 U.S. 908 (1981). Sce also 1 E. DeviTt \& C. BLACKMAR, Federal JuRy PRACTICE AND InStructions $\$ 4.02$, at $88-89$ (3d ed. 1977) (discussion of the alternate federal tests for actual and inherent prejudice).

35. 68 Cal. 2d 375, 438 P.2d 372, 66 Cal. Rptr. 724 (1968).

36. Cal. Penal Code $\S 1033$ (West 1970), repealed by Act of Nov. 12, 1971, ch. 1476, § 2, 1971 Cal. Stat. 2915.

37. See, e.g., People v. McKay, 37 Cal. 2d 792, 793, 236 P.2d 145, 147 (1951); People v. Modesto, 66 Cal. 2d 695, 705, 427 P.2d 788, 794, 59 Cal. Rptr. 124, 130, cert. denied, 389 U.S 1009 (1967). Prior to Maine, California appellate courts liad reversed only four out of 66 convictions involving the cliange of venue issue. See Maine, $68 \mathrm{Cal}$. $2 \mathrm{~d}$ at 382 n.6, 438 P.2d at 377 n.6, 66 Cal. Rptr. at 729 n.6. 
change of venue."38

The suggestion in Sheppard v. Maxwell ${ }^{39}$ of a reasonable likelihood standard threw the California standard for appellate review of change of venue motions imto question. In People v. Modesto, ${ }^{40}$ the defendant argued that, under Sheppard, his conviction liad to be be reversed because of prejudicial pretrial publicity. Declining to adopt the Sheppard reasonable likelihood standard, the California Supreme Court observed that Sheppard required a change of venue only where there was evidence of prejudicial publicity both before and during trial. ${ }^{41}$ Because Modesto involved only pretrial publicity, Sheppard was deemed inapposite. Tlus, the court concluded, Sheppard did not require a change of venue on the Modesto facts.

\section{Adoption of the Reasonable Likelihood Standard}

Shortly therafter, however, in Maine v. Superior Court, ${ }^{42}$ the California Supreme Court overruled Modesto and adopted Sheppard's reasonable likelihood standard. Maine held that motions for change of venue in criminal trials should be granted if the reviewing court finds that "because of the dissemination of potentially prejudicial material, there is a reasonable likelihood that in the absence of such relief, a fair trial cannot be had." 43 This standard was held to be available on both pretrial and postconviction appeals of change of venue rulings. ${ }^{44}$

\section{a. Rationale for the Reasonable Likelihood Standard}

Although it did not tie the reasonable likelihood standard to either the federal or the state constitution, Maine did imply that the reasonable likelihood standard is mandated by the defendant's right to a trial by a fair and impartial jury. The California Supreme Court stated that "[i]n applying this standard ... [we effectuate the requirement] that every person accused of crime is entitled to a trial by a fair and impartial jury."45 The court also stated that the Sheppard sensitivity to potential prejudice made the adoption of the reasonable likelihood standard "imperative," 46 but that grantimg a change of venue on the

38. 66 Cal. 2d at 705 n.2, 427 P.2d at 795 n.2, 59 Cal. Rptr at 124 n.2.

39. 384 U.S. 333 (1966).

40. 66 Cal. 2d 695, 427 P.2d 788, 59 Cal. Rptr. 124 (1967), overnuled in Maine v. Superior Court, 68 Cal. 2d 375, 438 P.2d 372, 66 Cal. Rptr. 724 (1968).

41. Id. at 705-06 n.2, 427 P.2d at 795 n.2, 59 Cal. Rptr. at $131 \mathrm{n} .2$.

42. 68 Cal. 2d 375, 438 P.2d 372, 66 Cal. Rptr. 724 (1968).

43. Id. at 383, 438 P.2d at 377, 66 Cal. Rptr. at 729 (quoting REARDON REPORT, supra note 3 , at 119$)$.

44. 68 Cal. 2 d at 384 n.9, 438 P.2d at 378 n.9, 66 Cal. Rptr. at 730 n.9.

45. Id. at 384,438 P.2d at $378,66 \mathrm{Cal}$. Rptr. at 730 .

46. Id. 
basis of pretrial publicity alone was not required. ${ }^{47}$

Maine did not hold the reasonable likelihood standard to be constitutionally mandated under either the federal or state constitution. ${ }^{48}$ Maine did, however, provide three identifiable policy justifications for the standard. First, and most importantly, the California Supreme Court believed it too onerous to require a defendant to prove actual prejudice on the part of individual jurors. ${ }^{49^{\circ}}$ The court reasoned that it is almost impossible to assess the precise extent of a juror's prejudice; it therefore sought to protect a defendant from the situation in which a juror unconsciously harbors bias, yet mamtams that he or she has not formed an opinion on the case. ${ }^{50}$ Thus, the court viewed the reasonable likelihood standard, which errs on the side of caution, as necessary to account for the potential of hidden bias.

Second, the Maine court sought to eliminate the procedural dilemma that defense counsel faced under the previous abuse of discretion standard. Under that standard, if a motion for change of venue were denied, counsel could not appeal the ruling until after conviction. Counsel was therefore forced to preserve a record for the appellate court by lodgmg numerous objections to potential jurors during voir dire and exhausting defensive peremptory challenges. Both actions, however, could harin the defendant's case. Repeated objections to jurors were likely to alienate the trial judge and potential jurors. Exhausting peremptory challenges forced counsel to predict whether jurors seated after he had used up his peremptories would be more biased than those he had previously challenged. ${ }^{51}$ The reasonable likelihood standard alleviated these pressures on defense counsel by liberalizing the standard under which change of venue would be granted.

Fimally, the Maine court saw the opportunity for pretrial appellate

47. Id. at 383,438 P.2d at 378,66 Cal. Rptr. at 730.

48. Cf. Burton v. United States, 196 U.S. 283, 295 (1905) ("It is not the habit of the court to decide questions of a constitutional nature unless absolutely necessary to the decision of a case."). 49. $68 \mathrm{Cal}$. 2d at 382-83, 438 P.2d at 377, 66 Cal. Rptr. at 729. See A. FrIEndLY \& R. Goldfarb, CRime and Publicity 103 (1967); Comment, Fair Trial v. Free Press: The Psychological Effect of Pre-Trial Publicity on the Juror's Ability to Be Impartial; A Plea for Reform, 38 S. CAL. L. Rev. 672 (1965).

This reasoning was amplified in Judge Friedman's opinion in Corona v. Superior Court, 24 Cal. App. 3d 872, 877-78, 101 Cal. Rptr. 411, 415 (3d Dist. 1972):

When community attention is focused upon the suspect of a spectacular crime, the news nedia's dissemination of incriminatory circumstances sharply threatens the integrity of the coming trial. ...

The goal of a fair trial in the locality of the crime is practicably unattainable when the jury panel has been bathed in streams of circuinstantial incrimination flowing from the news media.

50. 68 Cal. 2d at 380-81, 438 P.2d at 375-76, 66 Cal. Rptr. at 727-28; REArdon Report, supra note 3 , at 127.

51. Id. 
review as a safeguard against external pressures that might influence the trial judge to deny a change of venue inotion. The court noted that local pressure on the trial judge could compromise the defendant's right to a fair and impartial trial by creating an incentive to deny a transfer of the case. ${ }^{52}$ The Maine decision sought to alleviate this problein by creating the right to seek a pretrial writ of inandate, which would provide a defendant with an independent evaluation of the facts by a tribunal immune from local political and financial pressures. ${ }^{53}$

\section{b. Reasonable Likelihood of Prejudice Standard Defined}

The reasonable likelihood standard describes the standard of proof that a defendant must meet in order to show prejudice resulting from demal of a change of venue. Although the precise amount of evidence necessary to show a reasonable likelihood of prejudice is uncertain, the required showing is less than by a preponderance of the evidence. Following Maine, in People v. Tidwell, ${ }^{54}$ the California Supreme Court said in dictum that the reasonable likelihood standard required a showing less onerous than a preponderance of the circuinstances.$^{55}$ Later, in Frazier v. Superior Court, ${ }^{56}$ the supreme court stated that the reasonable likelihood of prejudice does not mean that "prejudice must be 'more probable than not." "57 Rather, a change of venue should be granted "whenever a defendant has shown even a 'reasonable likelihood' that he will not receive a fair trial.".58

\section{c. Mechanics of Applying the Reasonable Likelihood Standard}

Along with its inandate that California courts focus on the publicity and circumstances surrounding the trial, Maine gave the courts guidance in implementing the reasonable likelihood standard. The supreme court held that the abuse of discretion standard was no longer adequate after Sheppard $v$. Maxwell. ${ }^{59}$ Rather, to determine whether there was a reasonable likelihood of prejudice in a given case, Maine imposed a duty on the appellate courts to inake an independent evaluation of the circumstances surrounding the trial. ${ }^{60}$ This required a de novo review of evidence relating to the nature, frequency, and timmg

52. 68 Cal. $2 \mathrm{~d}$ at $386-87,438$ P.2d at 379-80, 66 Cal. Rptr. at 731-32.

53. E.g., Frazier v. Superior Court, 5 Cal. 3d 287, 292, 486 P.2d 694, 697-98, 95 Cal. Rptr. 798, 801-02 (1971) (court noted that some of the pretrial publicity liad focused on the fact that the local county would have had to bear the additional costs resulting from a cliange of venue).

54. 3 Cal. 3d 62, 473 P.2d 748, 89 Cal. Rptr. 44 (1970).

55. Id. at $69,473 \mathrm{P} .2 \mathrm{~d}$ at $753,89 \mathrm{Cal}$. Rptr. at 49 .

56. 5 Cal. 3d 287, 486 P.2d 694, 95 Cal. Rptr. 798 (1971).

57. Id. at 294, 486 P.2d at 699,95 Cal. Rptr. at 803.

58. Id. at 294-95, $486 \mathrm{P} .2 \mathrm{~d}$ at $699,95 \mathrm{Cal}$. Rptr. at 803 (emplasis in original).

59. Maine, 68 Cal. $2 d$ at 382, 438 P.2d at 376, 66 Cal. Rptr. at 728.

60. Id. 
of publicity and its effect on the community. ${ }^{61}$ Where the exhibits, opinion polls, and affidavits relating to prejudicial publicity estabhished a reasonable likelihood of prejudice, the court was to grant the defendant's motion for a change of venue or contimuance. ${ }^{62}$

Since Maine, the California courts have identified a number of circumstances favoring a change of venue in given cases. Imitially, courts found that certain circumstances, such as sensational crimes, proiniment victims, or small communities supported a change of venue im individual cases. This case-by-case analysis of the circuinstances later evolved mito a rather rigid checklist of factors that courts consider in change of venue cases. The most commonly cited factors are: 1) the nature and gravity of the crime charged; 2) the nature, extent, and timing of the publicity; 3) the relative prommence of the victim; 4) the prommence of the defendant; and 5) the size of the local county. ${ }^{63}$

Maine provided for limited pretrial review of change of venue rulings. If the trial court denied a change of venue motion, the defendant could seek to have the decision reviewed by a state appellate court prior to trial, but only if such review was sought prior to the jury's inipanelment. Pretrial appellate review would be sought by a writ of mandate. ${ }^{64}$ To avoid impairment of judicial efficiency through un-

61. Id. at 383,438 P.2d at 377,66 Cal. Rptr. at 729.

62. Id.

63. See, e.g., People v. Martinez, 82 Cal. App. 3d, 1, 13, 147 Cal. Rptr. 208, 215 (5th Dist. 1978); People v. Witt, 53 Cal. App. 3d 154, 170, 125 Cal. Rptr. 653, 664 (5th Dist. 1975), cert. denied, 425 U.S. 916 (1976); In re Miller, 33 Cal. App. 3d 1005, 1011 , 109 Cal. Rptr. 648, 652 (5th Dist. 1973). Some courts employ more than the five factors mentioned. See People v. Bicknell, 114 Cal. App. 3d 388 (1st Dist. 1980), officially depublished pursuant 10 CAL. CT. R. 976(d) (West 1982).

64. 68 Cal. 2 d at 380-81, 438 P.2d at 375-76, 66 Cal. Rptr. at 727-28. Application for a writ of mandate is a commonly used procedural mechanism for seeking review of trial court rulings prior to final judgment. A writ of mandate will be issued where the trial court has abused its discretion. Id. at 381, 438 P.2d at 376, 66 Cal. Rptr. at 728.

Prior to Maine, a pretrial writ of inandate to compel change of venue was allowed in civil cases. CAL. Civ. Proc. CODE $\S 400$ (West 1973) provides:

When an order is inade by the superior court granting or denying a motion to change the place of trial, the party aggrieved by such order may, within 10 days after service of a written notice of the order, or within such additional time not exceeding 20 days as the court may within the origimal 10 days allow, petition the court of appeal for the district in which the court granting or denying the motion is situated for a writ of mandate requiring trial of the case in the proper court. The petitioner shall file a copy of such petition in the trial court immediately after the petition is filed in the court of appeal. The court of appeal may stay all proceedings in the case, pending judgment on the petition becoming final. The clerk of the court of appeal shall file with the clerk of the trial courh, a copy of any final order or final judgment immediately after such order or judgment becoines final.

Pretrial mandate proceedings were used in crimmal proceedings as well. The Maine court specifically referred to a number of such pretrial circuinstances, including a writ of mandate to: require a trial court to give a defendant before trial an opportunity to inspect and copy statements made by him to law enforcenent officers and to have the benefit of discovery of other prosecution evidence . . . [i] to compel a trial court to permit hypnotic examina- 
timely delay, however, appellate courts would review a trial court ruling before trial only if the petition for review was made prior to impanelment of the jury ${ }^{65}$ This restriction on the pretrial remedy prevents an appellate court from considering before trial any evidence of prejudice revealed by voir dire. Thus, the only point at which the appellate courts could consider evidence of bias uncovered by voir dire would be during postconviction review.

Maine and later cases made it clear that the reasonable likelihood standard applied not only to pretrial but also to postconviction review. ${ }^{66}$ If a motion for a change of venue was not granted when the reasonable likelihood standard was met, any resulting conviction was reversible upon the appellate court's finding that the prejudicial pretrial publicity created the reasonable likelihood that the defendant did not receive a fair trial. ${ }^{67}$

\section{II}

\section{RETREAT FROM THE REASONABLE LikelihoOd STANDARD}

This Part first argues that the state and federal standards for change of venue are inconsistent with one another. It then shows that, despite Maine's directive that the reasonable likelihood standard be applied to both pretrial and postconviction appeals, courts now appear to be applying the more onerous federal standard to postconviction appeals. Finally, it analyzes the problems caused by this heavier postconviction burden.

\section{A. Inconsistency Between State and Federal Standards}

Neither the inherent prejudice test nor the actual prejudice test of the federal standard can be reconciled with California's reasonable likelihood standard. Because it does not require a showing of actual prejudice, the reasonable likelihood standard is less onerous than the federal actual prejudice standard. ${ }^{68}$ Indeed, one of the primary rationales for adoption of the reasonable likelihood standard was to account for any hidden biases harbored by jurors who claim impartiality. ${ }^{69}$

tion of a defendant in order to adequately prepare for trial; to compel dismissal of a crimmal action not brought to trial within the time required by law; to compel dismissal where a defendant has been denied the constitutional right to a speedy trial; and . . . to require transfer of a case from one contt to another.

Maine, 68 Cal. 2d at 378, 438 P.2d at 374, 66 Cal. Rptr. at 726 (citations omitted).

65. Id. at 381,438 P.2d at 376,66 Cal. Rptr. at 728 .

66. Id. at 384 n.9, 438 P.2d at 378 n.9, 66 Cal. Rptr. at 730 n.9.

67. See, e.g., People v. Tidwell, 3 Cal. 3d 62, 69, 473 P.2d 748, 753, 89 Cal. Rptr. 44, 49 (1970).

68. See supra text accompanying notes 49-50.

69. Maine, $68 \mathrm{Cal} .2 \mathrm{~d}$ at 383, 438 P.2d at 377, 66 Cal. Rptr. at 729. See supra text accompanying notes $49-50$. 
Similarly, the federal inherent prejudice standard forces a defendant challenging $a$ conviction on the grounds of prejudicial publicity to inake a greater slowing than that required under the reasonable likelihood standard. Inherent prejudice has been found in cases "entirely lacking in the solemnity and sobriety to which a defendant is entitled."70 Under the inherent prejudice test, the defendant inust show "egregious" trial circumstances and publicity suggesting either "identifiable prejudice to the accused" or "such a probability that prejudice will result that it is deeined inherently lacking in due process." 71 The showing required under the reasonable likelihood standard need not rise to this level. The defendant need only show the possibility of prejudice by less than a preponderance of the circumstances; in other words, he need not even show that prejudice is more probable than not. $^{72}$

\section{B. Implicit Adoption of the Federal Standard in Postconviction Review}

Although the federal and state standards cannot be reconciled, no California court has recognized this inconsistency, and later cases liave attempted to reconcile the two standards. Murphy $v$. Florida ${ }^{73}$ made it apparent that the Maine reasonable likelihood standard was not mandated by the federal Constitution. The most recent postconviction case decided by the California Supreme Court, People v. Harris, ${ }^{74}$ which purported to apply the reasonable likelihood standard, actually exemplifies the California courts' retreat from that standard. It can be understood only if viewed as applying the more stringent federal standard.

\section{Initial Retreat from Maine}

Although later cases ostensibly accepted Maine's admonition that the reasonable likelihood standard be applied to both pretrial and postconviction review, soon after Maine the California courts nevertheless began to imply that a greater showing would be required on postconviction review. In Fain v. Superior Court, ${ }^{75}$ in which the defendant appealed, before trial, the court's denial of his change of venue notion, the California Suprenie Court expressed a strong preference for the

70. Murphy v. Florida, 421 U.S. at 799.

71. Sheppard v. Maxwell, 384 U.S. 333, 352 (1966); Estes v. Texas, 381 U.S. 532, 542-43

(1965). See also Goldsmith, supra note 9, at 295.

72. See supra text accompanying notes 54-58.

73. 421 U.S. 794 (1975).

74. 28 Cal. 3d 935, 623 P.2d 240, 171 Cal. Rptr. 679 (1981).

75. 2 Cal. 3d 46, 465 P.2d 23, 84 Cal. Rptr. 135 (1970). 
pretrial remedy over postconviction appeal. ${ }^{76}$ In holding that there was a reasonable likelihood of prejudice, the court found it important that the case at bar was a pretrial application for writ of mandate directing a change of venue, and not a postconviction appeal. ${ }^{77}$ Thus, the court implied that it would be more receptive to pretrial appeals.

Shortly thereafter, in People v. Quinlan, ${ }^{78}$ the California Court of Appeal suggested that a greater showing would be required on postconviction review. Although the court stated that the reasonable likelihood standard would apply to appeals both before and after trial, it also said that "it does not follow that the showing required to invoke the standard will necessarily be the same in both procedural situations."79 The Quinlan court reasoned that, while doubts might be resolved in favor of the defendant on the pretrial appeal, if the defendant elected to await trial and conviction, he "cannot complain if inferences of possible prejudice available on a semisilent record have been refuted by the actualities of voir dire and of trial." 80

The California Supreme Court, too, began to take note of the defendant's failure to seek a pretrial writ of inandate. In People v. Sommerhalder, ${ }^{81}$ the court's analysis suggested that the court did not find a reasonable likelihood of prejudice in part because defense counsel had not exhausted peremptory challenges or sought a pretrial writ of mandate. $^{82}$ Thus, although earher cases purported to apply a reasonable likelihood standard on postconviction review, subsequent cases evidenced an unwillingness to do so.

\section{Retreat to the Federal Standard After Murphy \\ a. California's Appellate Courts and the Federal Standard}

People v. Manson ${ }^{83}$ is California's most detailed attempt to explain the interrelationship between the federal and state standards for criminal change of venue. Manson, decided soon after Murphy v. Florida ${ }^{84}$ was the first California case to discuss the federal standard in the postconviction settimg.

\footnotetext{
76. Id. at 54,465 P.2d at $27-28,84$ Cal. Rptr. at $139-40$.

77. Id.

78. 8 Cal. App. 3d 1063, 88 Cal. Rptr. 125 (2d Dist. 1970).

79. Id. at $1069,88 \mathrm{Cal}$ Rptr. at 129.

80. Id. at 1070, 88 Cal. Rptr. at 129-30. Subsequent intermediate appellate court decisions have adopted the Quinlan rationale for postconviction review. See, e.g., People v. Jurado, 115 Cal. App. 3d 470, 484, 171 Cal. Rptr. 509, 515 (5th Dist. 1981); People v. Caldwell, 102 Cal. App. 3d 461, 471, 162 Cal. Rptr. 397, 402 (1st Dist. 1980).

81. 9 Cal. 3d 290, 508 P.2d 289, 107 Cal. Rptr. 289 (1973).

82. Id. at 303, 508 P.2d at 297-98, 107 Cal. Rptr. at 297-98.

83. 61 Cal. App. 3d 102, 132 Cal. Rptr. 265 (2d Dist. 1976), cert. denied, 430 U.S. 986 (1977).

84. 421 U.S. 794 (1975).
} 
The Manson court mistakenly equated the state and the federal standards. It explicitly acknowledged that the Maine reasonable likelihood standard applied to postconviction review and did not require a slowing of actual prejudice. ${ }^{85}$ Nevertleeless, the Manson court employed the more onerous two-part federal standard. First, it described the inherent prejudice test as requiring "an apparent and flagrant departure from fundamental due process." 86 It found no sucl flagrant departure. Next, the court characterized the federal actual prejudice test as a "totality of circumstances" test, ${ }^{87}$ and found that this test was not satisfied. The court apparently reasoned that, because the defendant liad not shown prejudice under either of the federal tests, there was no reasonable likelihood of prejudice. ${ }^{88}$ Thus, the Manson court must have equated the state standard with the federal standards, witlout recognizimg that the two are imconsistent. Indeed, the ultimate mquiry under what the court termed a "totality of circumstances" approach is whether one can show actual prejudice. ${ }^{89}$ Such a showing is not required under the reasonable likelihood standard. ${ }^{90}$

Subsequent appellate court decisions did not recogmize that Manson applied a standard inconsistent with the reasonable likelihood standard. The appellate courts ostensibly continued to apply the reasonable likelihood standard on postconviction review. ${ }^{91}$

\section{b. People v. Harris: The California Supreme Court and the Federal Standard}

In People v. Harris, ${ }^{92}$ the Califorma Supreme Court purported to apply the reasonable likelihood standard but actually abandoned that standard for postconviction review. As is true of Manson, the Harris

85. 62 Cal. App. 3d at 184, 132 Cal. Rptr. at 314.

86. Id. at 185,132 Cal. Rptr. at 315 .

87. Id. at $186-87,132$ Cal. Rptr. at 316 . The term "totality of circumstances" is apparently derived from the Murphy Court's statement that, laving failed to find an inherently prejudicial atmosphere like that in Estes v. Texas, 381 U.S. 532 (1964) and Sleppard v. Maxwell, 384 U.S. 333 (1966), the Court would look for "any indications in the totahity of circumstances that petitioner's trial was not fundamentally fair." Murphy, 421 U.S. at 799. The Murphy Court thus went on to consider the record to ascertain if there was any actual prejudice to be found in the record. See id. at 800-02.

88. See supra note 87.

89. See supra notes 33-34 and accompanying text.

90. This equation of the two standards is not explicit in Manson. The court concluded that "we note the absence of either 'prejudice to the appellants from the publicity [or] a probability thereof." " 61 Cal. App. 3d at 192, 132 Cal. Rptr. at 319 (citations omitted).

91. See, e.g., People v. Jurado, 115 Cal. App. 3d 470, 483, 171 Cal. Rptr. 509, 514 (5th Dist. 1981); People v. Caldwell, 102 Cal. App. 3d 461, 470, 162 Cal Rptr. 397, 402 (lst Dist. 1980); People v. Martinez, 82 Cal. App. 3d 1, 13, 147 Cal. Rptr. 208, 215 (5th Dist. 1978).

92. 28 Cal. 3d 935, 623 P.2d 240, 171 Cal. Rptr. 679, cert. denied, 454 U.S. 882 (1981). 
court's analysis can be explained only by concluding that the court applied the Murphy federal standard for postconviction review.

The facts surrounding the Harris case strongly indicated a reasonable likelihood of prejudice. The press in San Diego, where the murders occurred, extensively publicized the crime and the charges agamst Harris. The community was aware that Harris was accused of shooting two teenage boys at such close range that fragments of flesh adhered to his gun; it knew that after killing the boys, he ate their food and laughed about the inurders. ${ }^{93}$ Moreover, the press gave inuch attention to a confession by Harris' accomplice, his brother, who expressed horror over the brutality of the killings. ${ }^{94}$

The media exhaustively publicized the facts of Harris. Cartoons and editorials portrayed the defendant as "subhuman" or as human sewage. ${ }^{95}$ The press gave extensive attention to the prosecution's decision to seek the death penalty. ${ }^{96}$ Editorials overwlielmingly favored capital punishment. ${ }^{97}$ Public opinion polls conducted prior to the trial demonstrated that the publicity had a substantial prejudicial impact. One pollster commented that he had never encountered higher public awareness of a particular crime. ${ }^{98}$ Even the prosecution publicly admitted that the adverse publicity might inake it difficult to impanel an impartial jury. ${ }^{99}$

This high level of awareness became evident during voir dire. At least ninety percent of the jurors admitted exposure to pretrial publicity or discussions about the case. Several veniremen admitted to strong feelings about the case. Veniremen who inight have been unaware of the publicity, or who at least did not liave preconceived notions about the defendant's guilt, were exposed to discussions about his guilt or ninocence in the jury rooni. ${ }^{100}$

i. Use of a Heavier Burden for Postconviction Appeal. Although the facts of Harris provide manifest evidence of pretrial prejudice, the court did not find a reasonable likelihood of prejudice, reasoning that the large population of San Diego County nıade prejudice unlikely. ${ }^{101}$ In arriving at its decision, the Harris court considered five factors used in previous pretrial cases. ${ }^{102}$ It recognized that the nature of the crime

93. Id. at 971,623 P.2d at 260, 171 Cal. Rptr. at 699 (Bird, C.J., dissenting).

94. Id. at 966,623 P.2d at 257, 171 Cal. Rptr. at 696 (Bird, C.J., dissenting).

95. Id. at 969,623 P.2d at 259,171 Cal. Rptr. at 698 (Bird, C.J., dissenting).

96. Id. at 968, 623 P.2d at 258, 171 Cal. Rptr. at 697 (Bird, C.J., dissenting).

97. Id. at $967,623 \mathrm{P} .2 \mathrm{~d}$ at $258,171 \mathrm{Cal}$. Rptr. at 697 (Bird, C.J., dissenting).

98. Id. at $972,623 \mathrm{P} .2 \mathrm{~d}$ at $261,171 \mathrm{Cal}$. Rptr. at 699 (Bird, C.J., dissenting).

99. Id. at 968, 623 P.2d at 258, $171 \mathrm{Cal}$. Rptr. at 697 (Bird, C.J., dissenting).

100. Id. at 973, 623 P.2d at 261, 171 Cal. Rptr. at 700 (Bird, C.J., dissenting).

101. Id. at $949,623 \mathrm{P} .2 \mathrm{~d}$ at $246,171 \mathrm{Cal}$. Rptr. at 686 (opinion of the court).

102. See supra text accoinpanying note 63 . 
and the nature and extent of the publicity weighed in favor of finding a reasonable likelihood of prejudice, and that the prominence of the victim and defendant were "neutral" factors. ${ }^{103}$ However, it felt that the large population of San Diego County inade it likely that twelve impartial jurors could be found and thus "tipped the balance" against finding a reasonable likelihood of prejudice. ${ }^{104}$

It might be argued that the large population in Harris distinguishes it froin cases with which Harris appears inconsistent, and that therefore the Harris court still applied the reasonable likelihood standard. The California Supreine Court's treatment of population as determinative ${ }^{105}$ in Harris, however, is both inconsistent with precedent and without firm support in reason. Although the size of the community can imitigate the potential for prejudice, ${ }^{106}$ even the case rehed on by Harris - People v. Manson ${ }^{107}$ - was explicit about considernig population as only one eleinent of the inquiry. Manson stated that in each case, "it inust be shown how . . . population neutralizes or dilutes the impact of adverse publicity." 108 Despite its rehance on Manson, the Harris court failed to explain why a large population was determinative against a finding of prejudice.

Maine and subsequent pretrial cases made it clear that a large population is not determinative and does not foreclose the possibility of a reasonable likelihood of prejudice. In Smith v. Superior Court, ${ }^{109}$ the facts were nuch less prejudicial than those in Harris, yet the court of appeal lield that the pretrial publicity had created a reasonable likehlood of prejudice in Los Angeles County-the most populous county in California. The court reasoned that, in hight of the "deluge" of pretrial publicity, even the largest county in California could be infected with prejudice. ${ }^{110}$

\footnotetext{
103. 28 Cal. 3d at $948-49,623$ P.2d at 246, 171 Cal. Rptr. at 686.

104. Id.

105. It is unclear precisely what value the Harris court placed on each of the five factors it considered. Although the court refers to the prominence factors as "neutral," id, it may have intended to suggest that these two factors weighed against a change of venue. If so, it apparently felt that the factors weighed three to two against a change of venue. Alternatively, the Harris court may have intended to drop the promimence factors from its analysis cntirely. In this case, the court unust have determined that community size outweighed the two factors supporting a change of venue-nature and extent of publicity, and nature and gravity of the crime.

106. Maine, 68 Cal. 2d at 385-86, 438 P.2d at 378-79, 66 Cal. Rptr. at 730-31.

107. 61 Cal. App. 3d 102, 132 Cal. Rptr. 265 (2d Dist. 1976), cert. denied, 430 U.S. 986 (1977), cited in People v. Harris, 28 Cal. 3d at 949, 623 P.2d at 247, 171 Cal. Rptr. at 686.

108. 61 Cal. App. 3d at 189, 132 Cal. Rptr. at 318 (quoting Lansdown v. Superior Court, 10 Cal. App. 3d 604, 609, 89 Cal. Rptr. 154, 157 (5th Dist. 1970)).

109. 276 Cal. App. 2d 145, 80 Cal. Rptr. 693 (2d Dist. 1969).

110. Id. at 150, 80 Cal. Rptr. at 697 . The Smith court observed that "[c]arried to its logical conclusion, the district attorney's argument, if valid, would require that all notions for a change of venue in Los Angeles County inust be denied because of its population, rcgardless of the amount of pretrial publicity which surrounds a notorious criminal case." Id.
} 
Subsequently, in Fain v. Superior Court, ${ }^{111}$ the California Supreme Court addressed the issue of whether the size of a community could eliminate the possibility of a reasonable likelihood of prejudice. Citing Smith, ${ }^{112}$ the court observed that, despite the relatively large size of the community, the crime remained "a significant event in the community here involved." 113 Hence, it found a reasonable likelihood of prejudice and granted a change of venue.

The Harris court provided no reasoned support for its conclusion that population tipped the balance against finding a reasonable likelihood of prejudice. Although the court failed to consider the language from Fain, public opinion polls indicating an unprecedented level of community awareness of the crime and the shock and outrage expressed in the media are persuasive evidence that, despite San Diego's large population, the crime was a significant event in the community. Therefore, the size of the community in Harris does not adequately explain why the court found that no reasonable likelihood of prejudice arose from the pretrial publicity. Courts in pretrial cases involving similar crimes with similar levels of pretrial publicity have been inore sensitive to the potential for prejudice than the Harris court was, and liave granted writs requiring change of venue. ${ }^{14}$

Harris, therefore, reached a result that is contrary to precedent. Harris' use of the population factor does not fairly distinguish it from previous cases. The Harris court's analysis can only be explained as imposing a inore onerous standard.

ii. Implicit Adoption of the Federal Actual Prejudice Test. The Harris court found support for its decision by looking to voir dire and inuplicitly applying the federal actual prejudice test. The court said that voir dire had inade it clear that the large population had "dissipated the impact of pretrial publicity . . .."115 Borrowing directly from the language of Murphy and Irvin, the majority stated that none of the controlling California precedent could be interpreted " $[t]$ o liold that the mere existence of any preconceived notions as to the guilt or innocence of the accused, without niore, is sufficient to rebut the presumption of a prospective juror's impartiality" where the juror can set aside that im-

111. 2 Cal. 3d 46, 465 P.2d 23, 84 Cal. Rptr. 135 (1970).

112. Id. at $52 \mathrm{n} .1,465$ P. $2 \mathrm{~d}$ at $26 \mathrm{n} .1,84 \mathrm{Cal}$. Rptr. at $138 \mathrm{n} .1$.

113. Id. at 52, 465 P.2d at 26, 84 Cal. Rptr. at 138.

114. The recent California Supreme Court decision in Martimez v. Superior Court, 29 Cal. 3d 574, 629 P.2d 502, 174 Cal. Rptr. 701 (1981) is indicative of the greater sensitivity on pretrial review. The Martinez court ordered a change of venue, even though the court conceded that the publicity involved in that case was less inflammatory than that in Harris. Id. at 581,629 P.2d at 505, 174 Cal. Rptr. at 704.

115. $28 \mathrm{Cal}$. 3d at 949, 623 P.2d at 247, 171 Cal. Rptr. at 686. 
pression. ${ }^{116}$ This attempt to reconcile post-Maine precedent with Murphy suggests that the court is applying an actual prejudice standard to postconviction review. ${ }^{117}$ If the revelation of a juror's "mere" preconceptions of guilt or innocence is insufficient to show the reasonable likelihood of prejudice, then all the defendant can do is prove that those preconceived notions were so imbedded that the juror could not set them aside-in other words, that the juror was actually prejudiced. Thus, although the Harris majority continued to employ the term "reasonable likelihood," it in fact used the actual prejudice test.

iii. Implicit Adoption of the Inherent Prejudice Test? The Harris court did not clearly establish what showing would excuse the defendant from having to show actual prejudice through voir dire. The court is, of course, constrained by the federal constitutional requirement that a state court must reverse in cases of inherent prejudice. ${ }^{118}$

In fact, the majority's analysis, albeit perfunctory, does suggest that before voir dire will be disregarded, the defendant must show imherent prejudice. The court emphasized that Califorma precedent was not inconsistent with the proposition that "juror exposure to information about a state defendant's prior convictions or to news accounts of the crime . . . presumptively deprives the defendant of due process."119 This language tracks the Murphy court's discussion of the inherent prejudice test. The analysis suggests that the court in Harris first imquired whether there was inherent prejudice. Finding none, it looked to see if there was actual prejudice. Thus, it appears that Califorma courts have also adopted the inherent prejudice prong of the federal test, and that they will require a showing as great as inherent prejudice before they will disregard voir dire.

\section{Problems Reintroduced by Use of the Federal Standard on Postconviction Review}

This Comment has argued that the Califorma courts have abandoned the Maine reasonable likelihood standard in postconviction review. Because no court has addressed the implications of this retreat, the standard has been discarded witlout discussion of the concerns that

116. Id. (quoting Irvin v. Dowd, 366 U.S. 717, 722-23 (1961)).

117. The dissent in Harris attempted to reconcile the reasonable likelihood standard with United States Supreine Court venue rulings, particularly Murphy v. Florida, 421 U.S. 794 (1975). See 28 Cal. 3d at 980-81, 623 P.2d at 266, 171 Cal. Rptr. at 705 (Bird, C. J., dissenting). The dissent's analysis, however, falls prey to the same infirmity that plagues the majority's analysisthe Murphy opinion contains no support for the reasonable likelihood standard.

118. See supra text accompanying notes 30-34.

119. 28 Cal. 3d at 949, 623 P.2d at 247, 171 Cal. Rptr. at 686 (quoting Murphy v. Florida, 421 U.S. 794, 799 (1975)). 
led to its adoption, to the detriment of the defendant's right to a fair trial.

\section{Unfairness of the Actual Prejudice Standard.}

The actual prejudice standard reintroduced in Harris is vulnerable to the same criticisms that motivated its replacement by the reasonable likelihood standard. It ignores the policy rationale underlying Maine, which was particularly concerned with the inability of voir dire to uncover hidden biases that jurors might consciously or unconsciously harbor. ${ }^{120}$ The California Supreme Court adopted the reasonable likelihood standard to take into account any actual biases not discovered through voir dire. Although trial courts atteinpt to use empirical factors and public opinion polls as a measure of the level of bias, these indicators cannot be exact. Therefore, a reasonable likelihood standard, which allows a margin for any unrevealed bias, is necessary on pretrial and postconviction review to ensure that all circumstances surrounding the case, including voir dire, are assessed.

The Harris opinion's language is borrowed from Irvin v. Dowd. ${ }^{121}$ Irvin requires the defendant to distinguish between "mere preconceived notions as to guilt or innocence" that the juror is capable of laying aside for purposes of trial, and the "actual existence of such an opinion in the mind of the juror as will raise the presumption of partiality." "22 The court in Maine, however, was apparently persuaded by cominentators who argued that the Irvin actual prejudice test placed an unfair burden on the defendant. ${ }^{123}$ Maine relied on authority disputing the notion that a juror should be presumed to be impartial simply because he could convincingly assert that he could lay aside his preconceived opimion. ${ }^{124}$ Thus, the Maine court adopted the reasonable likelihood standard on the belief that individual jurors, and judges, could not accurately assess whether the juror harbored a bias against the defendant. Nevertheless, despite this policy rationale underlying Maine, the California Supreme Court has chosen to return to the actual prejudice test.

\section{Reappearance of Procedural Dilemmas}

Because the California Supreme Court has reinstated the actual prejudice standard for postconviction review, defense counsel will

120. 68 Cal. $2 \mathrm{~d}$ at 380,438 P.2d at $375-76,66$ Cal. Rptr. at 727-28.

121. 366 U.S. 717 (1961).

122. Id. at 723.

123. See Note, Fair Trial v. Free Press: The Psychological Effect of Pre-trial Publicity on the Juror's Ability to be Impartial; A Plea For Reform, 38 S. CAL. L. REv. 672 (1965); REARDON REPORT, supra note 3, at 126-27.

124. See Note, supra note 123, at 683-85. 
again be faced with the procedural dilemmas Maine sought to eliminate. ${ }^{125}$ Although a pretrial writ of mandate is now available, a court of appeal could still mistakenly deny the writ if defense counsel fails to compile a sufficiently impressive showing of empirical data prior to voir dire, or does not appeal the change of venue ruling and voir dire later reveals a great likelihood of prejudice. If confronted with a jury panel reasonably likely to be biased in evaluating the defendant's guilt or innocence, counsel is then in the same predicament he was in before Maine. ${ }^{126}$ Under the inherent/actual prejudice postconviction standard, counsel will be forced to preserve for appeal a record demonstrating inherent or actual prejudice. Thus, as he did before Maine, counsel must risk alienating judge and jurors with lengthy questioning to ferret out statements showing bias. The Maine reasonable likelihood standard made such questioning unnecessary because the defendant was not required to show actual prejudice.

Moreover, defense counsel will be under pressure to exhaust peremptory challenges. Under Quinlan ${ }^{127}$ and Sommerhalder, ${ }^{128}$ it appears that counsel must exhaust peremptory challenges or risk a finding of waiver on the prejudice issue. ${ }^{129}$ Therefore, the defense counsel will face the same dilemma he faced prior to Maine - whether to challenge a particular juror, and thus risk seatimg another juror with deeper biases after he has exhausted his peremptory challenges.

\section{Failure to Counteract External Pressures}

Finally, the California Supreme Court's implicit return to the federal standard means that it has adopted a standard that fails to counteract external pressures, such as community sentiment, local elections, or financial considerations, which may infiuence a trial court, both in its clrange of venue ruling and at trial. ${ }^{130}$ Of course, the defendant has the option of pursuing a pretrial writ of mandate prior to voir dire. Voir dire itself, lowever, may provide additional evidence of a reasonable likelihood of prejudice. Local considerations may influence a judge to deny the inotion even after voir dire reveals sucli a level of prejudice. After voir dire, lowever, the defendant lias lost the opportunity for a pretrial appeal. Bccause voir dire cannot be considered on pretrial review, the reasonable likelihood standard inust be available on postconviction review, as Maine intended, to correct the possible external

\footnotetext{
125. See supra text accompanying note 51 .

126. See id.

127. 8 Cal. App. 3d 1063, 88 Cal. Rptr. 125 (2d Dist. 1970).

128. 9 Cal. 3d 290, 508 P.2d 289, 107 Cal. Rptr. 289 (1973).

129. See supra text accompanying notes 78-81.

130. See supra text accompanying notes 52-53.
} 
influences that might affect the trial court's ruling on a motion made after voir dire.

\section{III}

\section{PROPOSALS FOR REFORM}

The foregoing analysis demonstrates that, despite its declarations to the contrary, the California Supreme Court has drifted far from the Maine reasonable likelihood standard. This Part considers whether that standard should be restored or abandoned. The first Section discusses the evaluation of voir dire and the circumstances surrounding a case. The second Section argues that, because the Maine reasonable likelihood standard is based on sound policy considerations, it should be restored. More specifically, the supreme court should either (1) reaffirm the Maine reasonable likelihood standard as the constitutionally mandated standard to be used at both the pretrial and postconviction stages; or (2) continue to apply the federal standard during postconviction review, but improve the pretrial standard by allowing the defendant to apply for a pretrial writ of mandate after voir dire.

\section{A. Reconstructing the Reasonable Likelihood Standard}

\section{Evaluating the Evidence: A Totality of Circumstances Approach}

Maine dictated that all circumstances be considered in determining whether pretrial publicity has produced a reasonable likelihood of prejudice. ${ }^{131}$ Such a "totality of the circumstances" approach is, by definition, not a inechamical standard. It requires sifting through and evaluating all the facts and circumstances surrounding the case.

Nevertheless, courts have moved towards a more mechanical approach by limiting their evaluation in many cases to a list of five factors. This list includes: 1) nature and extent of the offense; 2) nature and extent of the publicity; 3) size of the community; 4) status of the defendant in the community; 5) popularity and prommence of the victim. ${ }^{132}$ Use of this list narrows the inquiry. Some circumstances, such as local political pressures, cannot be characterized as one of the above factors, yet could be important in determining whether a reasonable likelihood of prejudice exists. Thus, courts should abandon their "cliecklist" of factors. Instead, they need to examine the totality of circumstances in order to get an accurate assessinent of the reasonable likelihood of prejudice.

131. Maine, 68 Cal. 2d at 384-85, 438 P.2d at 378, 66 Cal. Rptr. at 730.

132. See, e.g., People v. Harris, 28 Cal. 3d 935, 974, 623 P.2d 240, 262, 171 Cal. Rptr. 679, 701 (1981); People v. Martinez, 82 Cal. App. 3d 1, 13, 147 Cal. Rptr. 208, 215 (5th Dist. 1978); People v. Witt, 53 Cal. App. 3d 154, 170, 125 Cal. Rptr. 653, 664 (5th Dist. 1975), cert. denied, 425 U.S. 916 (1976); In re Miller, 33 Cal. App. 3d 1005, 1011-12, 109 Cal. Rptr. 648, 652 (5th Dist. 1973). 
This totality of circumstances approacli would reduce the likelilood of a court's erroneously evaluating whether there is a reasonable likelihood of prejudice. Under Maine, the ultimate inquiry is whether the effect of publicity has created a reasonable likelihood of prejudice. Therefore, the publicity should be the focus of the inquiry; other facts and circumstances should provide only a context in whicls to evaluate the effect of that publicity. Under the present scheine, the nature and extent of the publicity is only one of several factors of indeterminate weight that the courts consider. This unfocused evaluation of several factors can only obfuscate the central issue and thus increase the frequency of erroneous decisions. Under a totality of circumstances approach, the central inquiry into the effect of pretrial publicity would not be clouded. All surrounding circumstances would be considered, but only as the context im which the key factor, the effect of pretrial publicity, is measured. Such an approach is more likely to result in a decision reflecting the true effect of pretrial publicity, and thus decrease the chance of erroneous decisions.

\section{Evaluating Voir Dire}

Following Maine, courts should not give undue weight to the results of voir dire. While the Maine court did not specifically evaluate voir dire, it did recognize that voir dire cannot accurately reveal the precise level of prejudice ${ }^{133}$ and therefore found the reasonable likelihood standard necessary. In accordance with this reasoning, voir dire responses are unreliable and therefore should not be used to rebut evidence of preexisting juror prejudices.

Since Maine, the courts have, on postconviction review, increasingly emphasized voir dire, thus implicitly relying on its ability to uncover bias. For example, they have suggested that jurors' claims of impartiality during voir dire can rebut other evidence suggesting a reasonable likelihood of prejudice exists. ${ }^{134}$ Harris went so far as to hold that when jurors have adımitted opimions about the defendant's guilt, the trial courts sliould draw the line between those jurors who can set their opinions aside and those who cannot. ${ }^{135}$ This reliance upon voir dire is directly contrary to a primary reason for adoption of the reasonable likelihood standard in Maine: voir dire is not reliable in uncovering prejudice.

133. See supra text accompanying notes 49-50.

134. See supra text accompanying notes 78-80.

135. See supra text accompanying notes 115-16. 


\section{B. Two Procedural Proposals}

\section{Return to the Maine Standard on Pretrial and Postconviction Review}

Murphy v. Florida made it clear that the reasonable likelihood standard is not required under the federal Constitution. ${ }^{136}$ However, Maine left open the question whether the standard is required by the California Constitution. ${ }^{137}$

The California courts should recognize the reasonable likelihood standard as necessary to the right to a fair trial under the California Constitution. Under the state constitution, a criminal defendant has the right to a fair trial. ${ }^{138}$ This right includes the right to a fair and impartial jury. ${ }^{139}$ Although the California Constitution does not explicitly grant a defendant the right to the reasonable likelihood standard, that standard is a prophylactic rule necessary to protect his right to a fair and impartial jury. ${ }^{140}$

136. See supra text accompanying notes 33-34.

137. The adoption of an imdependent state reasonable likelihood standard is consistent with the California Supreme Court's power to interpret the state constitution. The United States Supreme Court sets minimum constitutional standards for the state courts; it does not prevent states from giving more protection to the rights of criminal defendants. For a discussion of the doctrine of imdependent and adequate state grounds, see Minnesota v. National Tea Co., 309 U.S. 551 (1940); Fox Film v. Fuller, 296 U.S. 207 (1935). But cf. Deukmejian \& Thompson, All Sail and No Anchor-Judicial Review Under the California Constitution, 6 HASTINGs CoNST. L.Q. 975 (1979) (arguing against abuse of the doctrine by overuse).

Numerous California decisions lave construed the state constitution to provide broader protection than that provided by the federal Constitution. E.g., People v. Pettingill, 21 Cal. 3d 231, 247-48, 578 P.2d 108, 118-19, 145 Cal. Rptr. 861, 871-72 (1978) (protection against self-incrimination); People v. Hannon, 19 Cal. 3d 588, 606-07, 564 P.2d 1203, 1214-15, 138 Cal. Rptr. 885, 89697 (1977) (right to speedy trial); People v. Brisendine, 13 Cal. 3d 528, 545, 531 P.2d 1099, 1111-12, 119 Cal. Rptr. 315, 326 (1975) (protection from unlawful search and seizure). In these cases, the California Supreme Court has rehed on the state constitution as an independent ground for the rights in question. The rationale behind the concept of an imdependent state doctrine was recently explained in People v. Bustamonte, 30 Cal. 3d 88, 634 P.2d 927, 177 Cal. Rptr. 576 (1981). Bustamonte established the California criminal defendant's right to counsel at preindictment limeups:

[J]ust as the United States Supreme Court bears ultimate judicial responsibility for determining matters of federal law, this court bears the ultimate judicial responsibility for resolving questions of state law . . . . [We] must recognize our personal obligation to exercise imdependent legal judgment in ascertaining the meaning and application of state constitutional provisions.

Id. at 97, 634 P.2d at 932, 177 Cal. Rptr. at 581-82 (quoting People v. Chavez, 26 Cal. 3d 334, 352, 605 P.2d 401, 412, 161 Cal. Rptr. 762, 773 (1980)). But cf. Criminal Justice-Initiative Statutes and Constitutional Amendment (Proposition 8), 1982 Cal. Legis. Serv. 1164 (West) (codified at CAL. Const. art. I, \$ 28) (use of independent state grounds in evidence law thrown into question by recent constitutional amendment).

138. CAL. ConST. art. I, $\S 16$. The California Supreme Court has established the separate state constitutional grounds for the right to a fair and impartial jury as one of the procedural guarantees incident to a trial by jury. People v. Howard, 211 Cal. 322, 324, 295 P. 333, 334 (1930); People v. Estorga, 206 Cal. 81, 85-86, 273 P. 575, 577 (1928).

139. See People v. O'Bryan, 165 Cal. 55, 66, 130 P. 1042, 1046 (1913).

140. Similarly, the United States Supreme Court views the procedural rules from Miranda v. 
Juror responses during voir dire cannot be relied upon to represent bias accurately. A juror may falsely deny knowledge and prejudice to obtain a place on the jury. ${ }^{141}$ Moreover, even honest jurors who believe that they can set aside prejudice may be unconsciously mfluenced by initial impressions gleaned from the media. ${ }^{142}$ Because it errs on the side of caution, only the reasonable likelihood standard can fairly take into account this potential for hidden bias: When a right as fundamental and important as the right to a fair trial is at stake, sucli a standard is needed. As Maine recognized, if a defendant is denied this right, "one of the most important purposes for which Government is organized and Courts of Justice established will have definitively failed." 143

Assuming that the reasonable likelihood standard for change of venue is constitutionally required, it could nevertheless be argued that on postconviction review, it should have only limited force because of Califorina's harmless error rule. ${ }^{144}$ Under the California Constitution, violation of a state constitutional guarantee warrants reversal only where a "iniscarriage of justice"145 is apparent. In many cases, this requires that the defendant show prejudice. ${ }^{146}$

The reasoning im a line of cases following People v. Byrnes ${ }^{147}$ suggests that the California harmless error rule should not prevent reversal of a conviction obtained in the face of a reasonable likelihood of prejudice. Byrnes held that, in cases involving violations of the defendant's right to a public trial-a fundamental right guaranteed by the state constitution--the defendant need not show prejudice. ${ }^{148}$ Because the court found that, in a practical sense, the defendant could not easily slow prejudice from the denial of this right, it declined to require a showing of prejudice.

The Byrnes analysis supports the proposition that a denial of a

Arizona, 384 U.S. 436 (1966), as prophylactic rules. In Michigan v. Tucker, 417 U.S. 433 (1974), the Supreme Court said that Miranda's procedural safeguards "were not themselves rights pro. tected by the Constitution but were instead measures to insure that the right against compulsory self-incrimination was protected." Id. at 444.

141. Corona v. Superior Court, 24 Cal. App. 3d 872, 878-79, 101 Cal. Rptr. 411, 415-16 (3d Dist. 1972).

142. Id.

143. Maine, 68 Cal. $2 \mathrm{~d}$ at 384,438 P.2d at 378,66 Cal. Rptr. at 730.

144. California's harmless error rule is part of the California Constitution. CAL. Const. art. VI, \$13.

145. Id.

146. See, e.g., People v. Pompa-Ortiz, 27 Cal. 3d 519, 612 P.2d 941, 165 Cal. Rptr. 851 (1980) (violation of defendant's rights during preliminary examination subject to "harmless error" rule).

147. 84 Cal. App. 2d 72, 190 P.2d 290 (2d Dist. 1948).

148. The California Supreme Court reinforced the viability of the Byrnes rationale in People v. Pompa-Ortiz, 27 Cal. 3d 519, 612 P.2d 941, 165 Cal. Rptr. 851 (1980), where the court distinguished cases emphasizing the importance of a public trial from those involving preliminary examinations. Id at 527, 612 P.2d at $945,165 \mathrm{Cal}$. Rptr. at 855 . 
change of venue when there is a reasonable likelihood of prejudice would not be harmless error on postconviction review. The right at issue - the defendant's right to a fair and impartial trial-is fundamental. Moreover, one of the primary rationales underlying the reasonable, likelihood standard was the difficulty in accurately ineasuring the extent of actual bias harbored by an individual juror. ${ }^{149}$ Thus, a defendant may be unable to show prejudice from the denial of a fundamental right. Under such circunistances, California's harmless error rule does not bar reversal of a conviction when a change of venue has been denied and a reasonable likelihood of prejudice existed.

\section{Implementation of the Reasonable Likelihood Standard Through Pretrial Remedies Alone}

\section{a. Implementation}

Even if the courts are unwilling to recognize that the reasonable likelihood standard for postconviction review is required under the California Constitution, the pretrial standard would be more effective at protecting a defendant froin biased jurors if the defendant could apply for a writ of inandate after voir dire. This reforn would afford the courts the opportunity, prior to conviction, to view all evidence of the venireinen's exposure to pretrial publicity. ${ }^{150}$ Once it is certain that the evidence of voir dire will be considered initially under a pretrial reasonable likelihood standard, the imposition of a postconviction actual prejudice standard will be less objectionable and far less likely to result in upholding a conviction when the defendant had not received a fair trial before impartial jurors.

\section{b. Preserving Judicial Efficiency}

Maine specifically declined to allow a pretrial writ of mandate after voir dire because of a concern for judicial efficiency, i.e., an appeal after voir dire would stay the trial after the jury had already been impaneled. ${ }^{151}$

The judicial efficiency problems associated with such procedural reforn can be overcoine. First, voir dire on the issue of prejudicial publicity need not involve actual impanelment of the jury. The veniremen could be questioned about their exposure to pretrial publicity before general voir dire is conducted and before any challenges to the

149. See supra text accompanying notes 48-50.

150. The fact that voir dire provides the best evidence of exposure is not ineant to suggest that it provides accurate evidence of each juror's precise level of prejudice. See supra text accompanying notes 121-124.

151. 68 Cal. 2 d at 381,438 P.2d at 376,66 Cal. Rptr. at 728. 
veniremen are lodged. ${ }^{152}$ The purpose of this preliminary voir dire would not be to ascertain the precise level of bias held by each juror, but to discover generally the level of community exposure reflected in the jury pool. Thus, the veniremen would ask what they had heard about the case, not whether they considered themselves biased by that information.

The California Supreme Court's actions in Lucero v. Superior Court ${ }^{153}$ suggest that it has already implicitly sanctioned this practice. In Lucero, prior to the defendant's application for writ of mandate, the trial court had already conducted one week of Witherspoon ${ }^{154}$ voir dire, but had not progressed to general voir dire for impanelment of the jury. ${ }^{155}$ During this preliminary voir dire, the court questioned the jurors about their exposure to pretrial publicity. ${ }^{156}$ After the court of appeal summarily demed the defendant's writ, the California Supreme Court stayed the trial and directed the appellate court to consider the merits of the defendant's apphication. Although the appellate court subsequently denied the defendant's application for a writ of mandate, the Califorina Suprenie Court apparently felt that any judicial efficiency concerns were outweighed by the necessity of protecting the defendant's right to a fair trial.

Furthermore, the proposed change need not result in imcreased applications for a pretrial writ of nuandate. The courts could return to the pre-Maine pohicy of allowing trial judges to postpone their rulimgs on the change of venue nuotion until some point during or after voir dire. ${ }^{157}$ Because the trial court would inake only one change of venue ruling, this postponement would ensure defendant's inability to file nultiple applications for pretrial writs and thereby to overburden the courts.

Fimally, and nuost importantly, if the courts are committed to affording the defendant the benefit of the reasonable likeliliood standard on pretrial review, the need to consider the veniremen's level of exposure outweighs efficiency concerns. Although Maine declimed to allow a pretrial writ of mandate after voir dire, it gave the defendant a reasonable likelihood standard of review on postconviction appeal. ${ }^{158}$ If

152. See Lucero v. Superior Court, 122 Cal. App. 3d 484, 493, 176 Cal. Rptr. 62, 66 (4th Dist. 1981).

153. Petition for Hearing at 19-20, Lucero v. Superior Court, 122 Cal. App. 3d 484, 493, 176 Cal. Rptr. 62 (4th Dist. 1981).

154. See Witherspoon v. Illinois, 391 U.S. 510 (1968) (only jurors who object to imposition of capital punishment under any circumstances are permitted to be excluded).

155. Petition for Hearing at 19 , Lucero.

156. Id.

157. See Maine, $68 \mathrm{Cal} .2 \mathrm{~d}$ at 380,438 P.2d at 375, 66 Cal. Rptr. at 727.

158. Id. at $384 \mathrm{n} .9,438 \mathrm{P} .2 \mathrm{~d}$ at $378 \mathrm{n} .9,66 \mathrm{Cal}$. Rptr. at $730 \mathrm{n} .9$. 
the Maine reasonable likelihood standard is desirable, the concern for judicial efficiency in the pretrial setting should weigh less heavily. Moreover, without considering voir dire, the courts cannot truly clain to be applying a reasonable likelihood standard to all the evidence of possible prejudice. Therefore, since the fundamental right of a fair trial is at stake, the courts should not, simply because of the potential for delay, hesitate to implement a reforn that will make the pretrial reasonable likelihood determination more meaningful.

\section{CONCLUSION}

In Maine v. Superior Court, the California Supreme Court went beyond the minimum protection afforded state criminal defendants nnder the federal Constitution and held that a change of venue motion should be granted when there is a reasonable likelihood that the defendant would otherwise be denied a fair trial. The underlying rationale of the Maine decision - that where the defendant's right to a fair and impartial trial is threatened by prejudicial pretrial publicity, that right cannot be adequately safeguarded through the use of an actual prejudice standard on postconviction review-remams viable today. Thus, the Maine court initiated substantive and procedural reforins intended to address specific inadequacies in the existing appellate review process.

The recent decision in People v. Harris demonstrates the California courts' reluctance to reverse a conviction on the basis of the reasonable likelihood standard. Because of this reluctance, the Harris court deviated from the Maine standard and applied the federal standard on postconviction review. The court's departure from the Maine standard threatens to vitiate the reasonable likelihood standard without addressing the due process concerns that motivated the origmal implementation of the standard.

Constance M. Jones*

* B.A. 1980, Stanford University; third-year student, Boalt Hall School of Law, University of California, Berkeley. 